Research Article

\title{
Genotoxicity assessment of Copaiba oil and its fractions in Swiss mice
}

Mara Ribeiro Almeida ${ }^{1}$, Joana D’Arc Castania Darin ${ }^{1}$, Lívia Cristina Hernandes ${ }^{1}$, Mônica Freiman de Souza Ramos ${ }^{2,3}$, Lusânia Maria Greggi Antunes ${ }^{1}$ and Osvaldo de Freitas ${ }^{4}$

${ }^{1}$ Departamento de Análises Clínicas, Toxicológicas e Bromatológicas, Faculdade de Ciências Farmacêuticas de Ribeirão Preto, Ribeirão Preto, SP, Brazil.

${ }^{2}$ Departamento de Medicamentos, Faculdade de Farmácia, Universidade Federal do Rio de Janeiro, Rio de Janeiro, RJ, Brazil.

${ }^{3}$ Departamento de Farmacologia Aplicada, Fundação Oswaldo Cruz, Rio de Janeiro, RJ, Brazil.

${ }^{4}$ Departamento de Ciências Farmacêuticas, Faculdade de Ciências Farmacêuticas de Ribeirão Preto, Ribeirão Preto, SP, Brazil.

\begin{abstract}
Copaiba oil-resin, extracted from the trunk of Copaifera, and traditionally used in folk medicine in the treatment of various disorders, has been shown to be an effective antiinflamatory, antitumor, antitetanus, antiseptic and antiblenorrhagea agent. As, there are few studies evaluating its genotoxicity, this aspect of the commercial oil-resin, and its volatile and resinous fractions, were evaluated in mice by comet assay and micronucleus (MN) test. A single dose of oil resin, volatile or resin fractions $(500 ; 1,000$ or $2,000 \mathrm{mg} / \mathrm{kg} \mathrm{b.w.)} \mathrm{was} \mathrm{administered} \mathrm{by} \mathrm{gavage.} \mathrm{The} \mathrm{chemical}$ compositions of Copaiba oil resin and its fractions was analyzed by gas chromatography. According to comet assaying, treatment with either one did not increase DNA damage, and as to MN testing, there was no alteration in the incidence of micronucleated polychromatic erythrocytes. Chromatographic analysis of the oil-resin itself revealed sesquiterpenes, diterpenic carboxylic acid methyl esters and high levels of $\beta$-caryophyllene. Thus, it can be assumed that the oil resin and volatile and resinous fractions from the commercial product are not genotoxic or mutagenic.
\end{abstract}

Key words: Copaiba oilresin, genotoxicity, comet assay, micronucleus.

Received: February 1, 2012; Accepted: May 21, 2012.

\section{Introduction}

In recent years, the use of innumerable medicinal plants has received extensive investigation for therapeutic purposes. They are used worldwide as self-prescribed home medicines, especially in developing countries, as an aid in basic health care in $60 \%-80 \%$ of the population (Agra et al., 2008). Of late, they have even become a source of compounds for the pharmaceutical industry (Tsuboy et al., 2010; Rispler and Sara, 2011). As bioactive compounds from plants have many biological activities, the appreciable biodiversity among Brazilian plants presents great potential in the development of new drugs for application in the treatment of human diseases (Balbani et al., 2009). The identification of any possible toxicological activity in plant bioactive substances through preclinical tests should precede their use in preventive health strategies.

The genus Copaifera, classified in the family Leguminosae, Caesalpinoideae, tribe Detarieae (Lewis,

Send correspondence to Lusânia Maria Greggi Antunes. Departamento de Análises Clínicas, Toxicológicas e Bromatológicas, Faculdade de Ciências Farmacêuticas de Ribeirão Preto, Avenida do Café s/n, 14040-903 Ribeirão Preto, SP, Brazil. E-mail: lusania@ fcfrp.usp.br.
2003), is distributed throughout Africa (four species), Central America (four species), South America (37 species), and probably Asia (one species). Nine occur in the Brazilian Amazon: C. reticulata (Ducke), C. duckei (Dwyer), C. glycycarpa (Ducke), C. martti (Hayne), C. guyanensis (Desf.), C. multijuga (Hayne), C. piresii (Ducke), C. publiflora (Benth) and C. paupera (Herzog). The species most frequently used to obtain oil are C. reticulata (70\%), C. guyanensis (10\%) and C. multijuga (10\%) (Lawrence, 1988).

Since the $16^{\text {th }}$ century, Copaiba oil-resins extracted from the trunk of Copaifera have been applied in folk medicine by the natives of north and northeastern Brazil, in the treatment of various diseases. Studies have shown that the beneficial effects of Copaiba are due to its antiinflamatory, antitumor, antitetanus, antiseptic and antiblenorrhagea properties. Usually, the resin is administered orally in natura, or applied in ointment form (Paiva et al., 2002; Biavatti et al., 2006; Silva et al., 2009). By reason of its traditional and widespread use, commercialization of Copaiba as an oil or in capsule form has become intense, to the point of being exported to other countries, such as France, Ger- 
many and the United States (Veiga and Pinto, 2002; Veiga et al., 2001).

Copaiba oil has great social and economic representation in the Amazon region, since it represents approximately $95 \%$ of the entire oil-resin production countrywise. Annual production is estimated to be 500 tons/year (Medeiros and Vieira, 2008; Brazil, 2011). Even considering its wide use in folk medicine, and in various pharmacological forms, it has not been officially registered as a phytochemical drug. Hence, an assessment of the cytotoxic and mutagenic potential of the resin becomes fundamental to so ensure its safe usage, prior to phytochemical drug development.

Studies on the medicinal plants in northern Brazil have been well documented in the medical literature, especially as regards Copaiba oil-resin (Tappin et al., 2004; Comelli Júnior et al., 2010), and its manifold therapeutic properties - antiinflammatory, antitumoral, antimelanoma, antiulcerogenic, antilipoperoxidation and antioxidant (Ohsaki et al., 1994; Paiva et al., 2002; Gomes et al., 2007; Silva et al., 2009; dos Santos et al., 2010). Furthermore, new lines of research have been developed, with the aim of analyzing the chemical components involved. There is, for example, evidence of healing and antiinflammatory properties in certain fractions of the diterpenes, sesquiterpenes, and kaurenoic and polyaltic acids, present in the pure oil (Tappin et al., 2004; Comelli Júnior et al., 2010).

Thus, considering that, although the Copaiba oilresin, widely used in folk medicine, is now commercially produced, with ample demonstration of its therapeutic potential, its possible effects in DNA damage have not yet been appraised. Hence, the aim was to evaluate the cytotoxic and genotoxic potential of oil-resin, and its volatile and resinous fractions in the liver, blood and bone-marrow cells of Swiss mice using the comet assay and micronucleus (MN) test.

\section{Materials and Methods}

\section{Chemical agents}

The oil-resins, donated through a producer cooperative, came from bulk raw material originally from the Tarauacá region, Acre State, Brazil. After receipt, the samples were transferred to and stored in amber glass bottles at $20-22{ }^{\circ} \mathrm{C}$.

Doxorubicin (DXR, Rubidox ${ }^{\circledR}$, CAS: 25316-40-9), purchased from the Laboratório Químico Farmacêutico Bergamo Ltda (São Paulo, Brazil), and methyl methanesulfonate (MMS, CAS: 66-27-3), obtained from SigmaAldrich (St Louis, MO, USA), were dissolved in distilled water, just before each experiment, all of which took place in minimal, indirect light. Ethidium bromide (CAS 1239-45-8), trypan blue (CAS 72-57-1), phosphate buffered saline (PBS), Tween ${ }^{\circledR} 20$ (CAS 9005-64-5), Giemsa (CAS 51811-82-6) and acridine orange (CAS 65-61-2), were all purchased from Sigma - Aldrich (St Louis, MO, USA). Fetal bovine serum (FBS), low melting point agarose (CAS 9012-36-6) and normal melting point agarose (CAS 9012-36-6), were purchased from Invitrogen (California, CA, USA). All the other chemicals were analytical grade products.

\section{Oil-resin partitioning and derivation}

Commercial oil-resin was submitted to exhaustive 2-day hydrodistillation (8-12 h), in a modified Clevenger apparatus, thereby generating a colorless volatile fraction and a viscous residue. The resinous fraction was decanted and allowed to dry at room temperature. Aliquots $(10-20 \mathrm{mg})$ of the original oil-resin and resinous fraction were dissolved in dichloromethane $(2 \mathrm{~mL})$ and treated with diazomethane. The methylated sample and volatile fraction were then analyzed through gas chromatography-flame ionization detection (GC-FID) and gas chromatographymass spectrometry (GC-MS).

\section{Gas chromatographic analysis}

GC-FID analysis was performed on a gas chromatograph (HP 6890N Network CG System), fitted with a 30 $\mathrm{m} 0.32 \mathrm{~mm} 0.25 \mu \mathrm{m}$ film thickness HP- 5 capillary column, operating in split mode at a ratio of 1:50 (split/splitless injector). Helium was used as the carrier gas (flow $2.5 \mathrm{~mL} / \mathrm{min}$; inlet pressure $26.06 \mathrm{psi}$ ). The initial oven temperature was kept at $110{ }^{\circ} \mathrm{C}$ for $2 \mathrm{~min}$, raised to $140{ }^{\circ} \mathrm{C}$ at $5{ }^{\circ} \mathrm{C} / \mathrm{min}$ and then raised to $290{ }^{\circ} \mathrm{C}$ at $20^{\circ} \mathrm{C} / \mathrm{min}$, where it remained for $10 \mathrm{~min}$. Sample injection volume was $1 \mu \mathrm{L}$ from a $3 \mathrm{mg} / \mathrm{mL}$ solution in $\mathrm{CH}_{2} \mathrm{Cl}_{2}$. The relative abundance of oil constituents was obtained from electronic integration measurements, using flame ionization detection (FID, $270{ }^{\circ} \mathrm{C}$. Subsequent GC-MS analysis was performed in an HP 6890N equipment fitted with a HP-5 MS capillary column (30 m $0.32 \mathrm{~mm} 0.25 \mu \mathrm{m}$ film thickness) and processed using MSD Productivity ChemStation Software (Hewlett Packard, Palo Alto CA, USA). Chromatographic conditions were the same as above. The mass analyzer operated at an ion source temperature of $280^{\circ} \mathrm{C}$, electron impact ionization energy of $70 \mathrm{eV}$, and an acquisition mass range of 40 to $500 \mathrm{~m} / \mathrm{z}(3.66 \mathrm{scan} / \mathrm{s})$. Individual sesquiterpene constituents in the oils were identified by calculating their $\mathrm{GC}$ retention indices, determined in reference to a homologous series of normal $\mathrm{C}_{10}-\mathrm{C}_{30}$ alkanes, and by comparing their fragmentation patterns in mass spectra with those from Wiley Library Software 59943B (Hewlett Packard, Palo Alto CA, USA) and data from the literature (Adams, 2007). Individual diterpenes were identified by comparing their mass fragmentation with data from the literature.

\section{Animals and treatments}

Healthy, male albino Swiss mice (Mus musculus), 7|8-weeks-old and weighing approximately $35 \mathrm{~g}$, were ob- 
tained from the Animal Center of Coordenadoria do Campus de Ribeirão Preto, Universidade de São Paulo (Brazil). The experimental protocols for this study were approved by the Local Ethics Committee for Animal Use from the Campus of Ribeirão Preto, USP, Brazil (register No. 140/2011). Procedures involving animals and their care were in accordance with the Canadian Council on Animal Care (Olfert et al., 1993). The mice were housed in polycarbonate cages with steel wire tops (four animals per cage) under standard room temperature $\left(22 \pm 2{ }^{\circ} \mathrm{C}\right)$, humidity $(55 \pm 10 \%)$, and 12 $\mathrm{h}$ light/dark cycle. They received standard food and fresh water ad libitum, and were divided into 11 groups of six animals per treatment. The micronucleus test and the comet assay were performed in the same animals.

The doses of oil-resin, and volatile and resinous fractions from commercial Copaiba oil-resin, were 500, 1,000 and $2,000 \mathrm{mg} / \mathrm{kg}$ b.w. The agents were administered in a single dose by gavage $24 \mathrm{~h}$ before euthanasia. The negative control (water), solvent control (Polyoxyethylenesorbitan monolaurate - Tween ${ }^{\circledR} 20$ ), and positive controls (DXR, $16 \mathrm{mg} / \mathrm{kg}$ i.p. or MMS, $50 \mathrm{mg} / \mathrm{kg}$ i.p.), were also evaluated. MMS was the positive control in comet assays and DXR in micronucleus tests. The dose of DXR ( $16 \mathrm{mg} / \mathrm{kg}$ b.w.) was selected based on its effectiveness in inducing chromosomal damage in rodents (Ribeiro et al., 2010). $24 \mathrm{~h}$ after treatment, the mice were anesthetized and peripheral blood was collected from the caudal vein to perform the MN tests. Immediately thereafter, the animals were euthanized by cervical dislocation, the femurs and liver were freed from adherent tissues and dissected out.

\section{Comet assay}

Liver samples were collected after euthanasia. The preparation of a single-cell suspension from liver was according to Tice et al. (2000). $0.2 \mathrm{~g}$ from each liver in $1 \mathrm{~mL}$ of chilled Hank's solution was placed in a Petri dish, and then sliced into fragments with scissors. Immediately prior to comet assaying, the viability of liver cells was defined by the trypan dye exclusion method. In a viable cell, trypan blue is not absorbed, but traverses that of cells with a compromised membrane.

Comet assays were under alkaline conditions ( $\mathrm{pH}<13$ ), according to Singh et al. (1988), and guidelines for using this assay in genetic toxicology (Tice et al., 2000). The liver cell suspension ( $80 \mu \mathrm{L}$ ), first mixed with $240 \mu \mathrm{L}$ of low melting point agarose dissolved in phosphate buffered saline, was then spread onto microscope slides precoated with $1.5 \%$ normal melting point agarose. These were then covered with a coverslip and kept at a temperature of $4{ }^{\circ} \mathrm{C}$ for $15 \mathrm{~min}$, prior to immersion in a freshly prepared lysis solution consisting of $2.5 \mathrm{M}$ of $\mathrm{NaCl}, 100 \mathrm{mM}$ of EDTA, $1 \%$ Triton X-100, and $10 \mathrm{mM}$ of Tris, $\mathrm{pH} \mathrm{10,} \mathrm{for}$ $24 \mathrm{~h}$ at $4{ }^{\circ} \mathrm{C}$. After lysis, the slides were placed in a horizontal electrophoresis unit containing $300 \mathrm{mM}$ of $\mathrm{NaOH}$ and $1 \mathrm{mM}$ of EDTA, $\mathrm{pH}<13$, for $20 \mathrm{~min}$ at an electric field strength of $1 \mathrm{~V} / \mathrm{cm}(25 \mathrm{~V}$ and $300 \mathrm{~mA})$ to allow the DNA to unwind and express alkali-labile sites and DNA breaks. This was followed by washing in a neutralization buffer (0.4 M Tris-HCl, $\mathrm{pH}$ 7.5) for $5 \mathrm{~min}$.

After drying at ambient temperature, the slides were fixed in absolute ethanol for $2 \mathrm{~min}$ and stored until analysis. Each slide was stained with $30 \mu \mathrm{L}$ ethidium bromide $(20 \mu \mathrm{L} / \mathrm{mL})$ and immediately analyzed. All took place in the dark or under dim light. Comet observation, at 400x magnification, was with a fluorescence microscope (Zeiss, Axiostarplus $\left.{ }^{\circledR}\right)$ equipped with an excitation filter of $515-560 \mathrm{~nm}$ and a barrier filter of $590 \mathrm{~nm}$. The comets were analyzed using public-domain Comet Image Analysis System software (CometScore software; TriTek, Sumerduck, VA). Data were based on 100 randomly selected nucleoids (50 nucleoids from each replicate slide). DNA damage was assessed by the percentage of DNA in the tail (\%DNA tail) and Olive moment.

\section{Micronucleus test in mouse bone marrow and peripheral blood cells}

Bone-marrow smearing and staining were according to the MacGregor et al. (1987) method. Briefly, before centrifuging both femurs were removed, and the respective bone marrow flushed out into a centrifuge tube with fetal calf serum. The resulting pellet was resuspended in $0.3 \mathrm{~mL}$ of supernatant. A drop of this suspension was then smeared onto a clean slide, air dried, and fixed in absolute methanol for $10 \mathrm{~min}$, ready for staining the following day with Giemsa (diluted with phosphate buffer, $\mathrm{pH}$ 6.8). Two thousand polychromatic erythrocytes (PCEs, immature erythrocytes) were analyzed, and the number of micronucleated PCE (MNPCE) recorded. The PCE/NCE (normochromatic erythrocytes) ratio among 500 erythrocytes (PCEs + NCEs) was determined for the same sample, to so evaluate the cytotoxic effect of any of the treatments.

Micronucleus testing of peripheral blood cells was performed according to the procedure described by Hayashi et al. (1990), which uses slides pre-stained with acridine orange. Blood samples were obtained by mouse caudal vein perforation, thereby collecting $5 \mu \mathrm{L}$ (one drop). Each sample was placed in the center of a pre-stained slide and covered with a cover-slip $(24 \times 50 \mathrm{~mm})$. The slides were then kept in the dark at $-20^{\circ} \mathrm{C}$ for a minimum of $24 \mathrm{~h}$ before cytological examination. The cell preparations were examined under a fluorescence microscope (Zeiss) with a blue $(488 \mathrm{~nm})$ excitation filter and a yellow $(515 \mathrm{~nm})$ emission (barrier) filter, using an oil immersion objective. 1,000 PCE per treated animal were analyzed and the proportion of micronucleated cells (MNPCE) counted.

\section{Statistical analysis}

Results are expressed as mean \pm standard deviation $(n=6 /$ group$)$. The data were submitted to multiple analysis of one way-ANOVA and post-hoc Tukey tests using 
GraphPad Prism 2.01 software program (GraphPad Software Inc., San Diego, USA). A value of $p<0.05$ was considered statistically significant for all the parameters evaluated.

\section{Results}

Data from comet analysis of liver cells appear in Table 1 . No increase in \%DNA tail, in mice treated orally with various doses of commercial oil-resin, and its volatile and resinous fractions, signifies the absence of genotoxic effects. Furthermore, there was no significant difference between solvent and negative controls, demonstrating that the solvent did not interfere with the results. As expected, compared to negative control and solvent groups, animals treated with MMS as positive control revealed a higher level of DNA damage $(p<0.05)$. The viability of liver cells was $>80 \%$ for each cell suspension, both in the control and treated groups (data not shown).

The results obtained from micronucleus assaying of all the treatments appear in Table 2. Bone-marrow cytotoxicity was evaluated by counting the PCE/NCE ratio in 500 erythrocytes, whereby it was shown that the commercial oil-resin and its volatile and resinous fractions, as well as positive control treatments, induced no change in $\mathrm{PCE} / \mathrm{NCE}$ ratio, when compared to negative or solvent control groups. There were no significant differences $(p>0.05)$ between the negative or solvent controls and the commercial-oil-resin treated groups in $\mathrm{MN}$ frequency in either bone
Table 1 - Percentage of DNA in the tail (\%DNA tail) and Olive moment obtained from liver cells of mice treated with different doses of oil-resin, and volatile and resinous fractions $(500,1,000$ or $2,000 \mathrm{mg} / \mathrm{kg}$ b.w.) from commercial Copaiba oil-resin and respective negative, positive (methyl methanesulphonate - MMS, $50 \mathrm{mg} / \mathrm{kg}$ b.w., i.p.) and solvent (Tween 20) controls.

\begin{tabular}{lcc}
\hline Treatments $(\mathrm{mg} / \mathrm{kg})$ & $\begin{array}{c}\text { \% DNA tail } \\
\text { Mean } \pm \text { SD }\end{array}$ & $\begin{array}{c}\text { Olive moment } \\
\text { Mean } \pm \text { SD }\end{array}$ \\
\hline Negative control & $5.84 \pm 0.58$ & $4.03 \pm 0.95$ \\
Solvent control & $8.37 \pm 3.85$ & $7.05 \pm 4.70$ \\
Positive control & $28.15 \pm 0.75^{\mathrm{a}, \mathrm{b}}$ & $26.03 \pm 3.19^{\mathrm{a}, \mathrm{b}}$ \\
\hline Oil-resin & & \\
500 & $4.05 \pm 1.31$ & $4.41 \pm 3.75$ \\
1000 & $4.16 \pm 1.63$ & $2.05 \pm 1.46$ \\
2000 & $5.21 \pm 1.80$ & $3.09 \pm 1.51$ \\
\hline Volatile fraction & & \\
500 & $11.42 \pm 4.40$ & $10.24 \pm 5.26$ \\
1000 & $9.59 \pm 4.73$ & $8.16 \pm 5.72$ \\
2000 & $6.88 \pm 2.19$ & $4.33 \pm 2.03$ \\
\hline Resin & & \\
500 & $10.09 \pm 4.66$ & $7.42 \pm 4.17$ \\
1000 & $8.94 \pm 3.01$ & $7.11 \pm 3.39$ \\
\hline
\end{tabular}

100 nucleoids were analyzed per animal, with six animals per group. ${ }^{\mathrm{a}} \mathrm{p}<0.05$ compared to negative control. ${ }^{\mathrm{b}} \mathrm{p}<0.05$ compared to solvent control. One way-ANOVA and post-hoc Tukey test.

Table 2 - Frequencies of micronucleated polychromatic erythrocytes (MNPCE) in bone marrow and peripheral blood of mice treated with different doses of oil-resin, and volatile and resinous fractions $(500,1,000$ or $2,000 \mathrm{mg} / \mathrm{kg}$ b.w.) from commercial Copaiba oil-resin, and respective negative, positive (Doxorubicin, $16 \mathrm{mg} / \mathrm{kg}$ b.w., i.p.) and solvent (Tween 20) controls.

\begin{tabular}{lcccc}
\hline Treatments (mg/kg) & \multicolumn{2}{c}{ Bone marrow erythrocytes* } & & Peripheral blood erythrocytes** \\
\cline { 2 - 3 } & MNPCE Mean \pm SD & PCE/NCE & & MNPCE Mean \pm SD \\
\hline Negative control & $3.83 \pm 1.78$ & $1.47 \pm 0.44$ & $1.50 \pm 1.04$ \\
Solvent control & $2.0 \pm 1.41$ & $1.42 \pm 0.27$ & $1.50 \pm 1.22$ \\
Positive control & $31.16 \pm 7.90^{\mathrm{a}, \mathrm{b}}$ & $1.31 \pm 0.14$ & $14.16 \pm 5.11^{\mathrm{a}, \mathrm{b}}$ \\
\hline Oil-resin & & & $1.66 \pm 1.50$ \\
500 & $2.83 \pm 1.72$ & $1.26 \pm 0.17$ & $1.16 \pm 0.75$ \\
1000 & $2.83 \pm 0.75$ & $1.74 \pm 0.68$ & $1.33 \pm 1.03$ \\
2000 & $2.66 \pm 0.81$ & $1.48 \pm 0.19$ & $1.33 \pm 1.03$ \\
\hline Volatile fraction & & & $0.83 \pm 0.70$ \\
500 & $2.16 \pm 1.16$ & $1.51 \pm 0.21$ & $1.33 \pm 1.03$ \\
1000 & $2.66 \pm 0.91$ & $1.41 \pm 0,21$ & \\
2000 & $4.16 \pm 1.72$ & $1.27 \pm 0.33$ & \\
\hline Resin fraction & & & $2.16 \pm 1.16$ \\
500 & $4.66 \pm 1.03$ & $1.32 \pm 0.27$ & $1.83 \pm 1.04$ \\
1000 & $2.50 \pm 1.51$ & $1.28 \pm 0.12$ & \\
\hline
\end{tabular}

*2,000 PCE were analyzed per animal, with six animals per group. $* * 1,000$ PCE were analyzed per animal. ${ }^{\mathrm{a}} \mathrm{p}<0.05$ compared to negative control. ${ }^{\mathrm{b}} \mathrm{p}<$ 0.05 compared to solvent control. One way-ANOVA and post-hoc Tukey test. 
marrow or peripheral blood cells, thereby demonstrating the absence of mutagenicity. In the positive control (DXR group), there was a significant increase in micronucleus frequency, in both bone marrow and peripheral blood erythrocytes, when compared to negative and solvent controls.
Chromatographic analysis of methylated oil-resin indicated sesquiterpenes (hydrocarbons and alcohol) and diterpenic carboxylic acid methyl esters. The composition of methylated oil-resin, volatile fractions, and resin with the retention indices used to identify sesquiterpenes, are presented in Table 3.

Table 3 - Relative abundance (\%) of the constituents of commercial Copaiba oil-resin.

\begin{tabular}{|c|c|c|c|c|c|}
\hline \multirow[t]{2}{*}{$\mathrm{RI}_{\text {lit }}{ }^{\mathrm{a}}$} & \multirow[t]{2}{*}{$\mathrm{RI}^{\mathrm{b}}$} & \multirow[t]{2}{*}{ Constituent $^{\mathrm{b}}$} & \multicolumn{3}{|c|}{ Relative peak area (\%) } \\
\hline & & & Oil resin & Volatile fraction & Resin \\
\hline 1338 & 1340 & $\delta$-Elemene & 0.38 & 0.65 & \\
\hline 1348 & 1350 & $\alpha$-Cubebene & 0.22 & 0.47 & \\
\hline 1376 & 1379 & $\alpha$-Copaene & 2.46 & 4.46 & \\
\hline 1390 & 1391 & $\beta$-Elemene & 1.02 & 1.53 & \\
\hline 1398 & 1403 & Cyperene & 0.36 & 0.60 & \\
\hline 1419 & 1423 & $\beta$-Caryophyllene (trans) & 51.78 & 70.01 & \\
\hline 1434 & 1439 & $\alpha$-Bergamotene (trans) & 1.07 & 1.58 & \\
\hline 1436 & 1441 & $\gamma$-Elemene & 0.92 & 1.19 & \\
\hline 1454 & 1465 & $\alpha$-Humulene & 8.57 & 10.91 & \\
\hline 1479 & 1483 & $\gamma$-Muurolene & 0.23 & 0.56 & \\
\hline 1484 & 1485 & $\alpha$-Amorphene & 1.14 & 1.35 & \\
\hline 1485 & 1488 & Germacrene D & 1.20 & 1.00 & \\
\hline 1490 & 1493 & $\beta$-Selinene & 0.56 & 0.65 & \\
\hline 1498 & 1499 & $\alpha$-Selinene & 0.53 & 0.30 & \\
\hline 1505 & 1509 & $\beta$-Bisabolene & 1.48 & 1.4 & \\
\hline 1523 & 1522 & $\gamma$-Cadinene & 1.40 & 1.27 & \\
\hline 1561 & 1565 & Germacrene B & 0.48 & 0.26 & \\
\hline 1572 & 1578 & Caryophyllenyl alchool & 0.63 & 0.27 & \\
\hline 1582 & 1589 & Caryophyllene oxide & 0.32 & 1.42 & \\
\hline 1640 & 1636 & epi- $\alpha$-Cadinol & 0.15 & & \\
\hline 1644 & 1642 & epi- $\alpha$-Muurolol & 0.43 & & \\
\hline \multirow[t]{14}{*}{1654} & 1651 & $\alpha$-Cadinol & 0.22 & & \\
\hline & & Eperuic acid & 0.46 & & 0.67 \\
\hline & & Copalic acid & 4.70 & & 32.07 \\
\hline & & Kovalenic acid & 0.30 & & 0.71 \\
\hline & & Danielic acid & 2.58 & & 16.70 \\
\hline & & Pinifolic acid & 0.58 & & 1.11 \\
\hline & & Agathic acid & 3.35 & & 11.95 \\
\hline & & Hydroxy-copalic acid & 5.08 & & 6.19 \\
\hline & & Acetoxy-copalic acid & 4.02 & & 26.98 \\
\hline & & Sesquiterpenes hydrocarbons & 78.80 & 98.19 & \\
\hline & & Sesquiterpenes oxygenated & 1.75 & 1.69 & \\
\hline & & Total sesquiterpenes & 75.55 & 99.88 & \\
\hline & & Diterpenes & 21.07 & & 96.38 \\
\hline & & Total identified & 96.62 & 99.88 & 96.38 \\
\hline
\end{tabular}

${ }^{a} \mathrm{RI}$ lit $=$ Retention Index. See Adams (2007).

${ }^{\mathrm{b}}$ Diterpene acids were analyzed as methyl esters derivatives. 
The commercial oleoresin showed high yields (v/v) of sesquiterpene hydrocarbons (78.8\%) and low ones for oxigenated sesquiterpenes $(1.75 \%)$. $\beta$-caryophyllene was the most abundant component (51.78\%). Furthermore, the number of caryophyllene-type compounds increased by the presence of $8.57 \%, 0.63 \%$ and $0.32 \%$ of $\alpha$-humulene, caryophyllene alcohol and caryophyllene oxide, respectively.

\section{Discussion}

The aim was to evaluate the acute genotoxicity and mutagenicity of the commercial oil-resin, and its volatile and resinous fractions, with a view to its application as a herbal therapeutic product. Comet assays and micronucleus tests in liver cells, peripheral blood and bone-marrow cells in mice were performed to determine Copaiba effects concerning DNA damage.

An important aspect in genetic toxicology is the choice of doses. In cases where the toxicity of the agent tested is unknown, it is recommended to evaluate doses either up to $2,000 \mathrm{mg} / \mathrm{kg}$, or up to the maximum solubility of the agent (Tice et al., 2000). In the present case, there were no available data on toxicity, cytotoxicity or genotoxicity of the oil-resin studied. Nonetheless, Gomes et al. (2007) showed that mice treated with Copaiba oil $(500 \mathrm{mg} / \mathrm{kg}$ b.w.) presented neither acute toxicity, nor alterations in behavior, lesions or stomach bleeding. $\mathrm{LD}_{50}$ (Lethal Dose) values were 3.9 and $4.3 \mathrm{~g} / \mathrm{kg}$ for Copaifera reticulata and Copaifera multijuga, respectively. Hence, in the present study, the doses chosen for the oil-resin, and volatile and resinous fractions were $500,1,000$ and $2,000 \mathrm{mg} / \mathrm{kg}$, respectively. Worthy of note: oil-resin presented problems with solubility above $1,000 \mathrm{mg} / \mathrm{kg}$.

The comet assay is a rapid and sensitive method for measuring DNA damage, through detecting DNA strand breaks, such as alkali-labile sites and incomplete excision repair events, in individual cells (Tice et al., 2000; Collins, 2004; Moller, 2006). Hence, an important factor in DNA damage assessed by this procedure, is DNA repair capacity, which, besides depending on the activity of several enzymes, is influenced by both the cell cycle phase and the rate of cell proliferation (Bonassi et al., 2007; Knudsen and Hansen, 2007). Furthermore, several tissues can be analyzed simultaneously for DNA damage. Even so, the liver is the most widely used, through being the main site in the metabolism of many drugs (Rothfuss et al., 2011).

The micronucleus test provides a simple and rapid form for indirectly measuring induced structural and numerical chromosome aberrations. Moreover, it is scientifically and regulatorily accepted by international agencies, principally supranational authorities, such as the Organization for Economic Cooperation and Development (OECD), International Conference on Harmonization (ICH) and European Union (EU) (Mavournin et al., 1990). In Brazil, the
Agência Nacional de Vigilância Sanitária (ANVISA) has recommended that the mutagenicity of herbal plants be evaluated (Brazil, 1996,).

The PCE/NCE ratio is another parameter that can be evaluated by micronucleus testing. The progression of cells from erythroblasts through the PCE stage to NCE, is an indicator of acceleration or inhibition in erythropoiesis, and thus, a decrease in this ratio indicates cytotoxicity (Venkatesh et al., 2007). The results of the present study showed that oilresin, volatile and resinous fractions from commercial Copaiba oilresin and the positive control treatments did not decrease the PCE/NCE ratio when compared with the negative or solvent control groups, indicating that treatment with Copaiba did not induce cytotoxicity in the bone marrow.

Positive control compounds in micronucleus tests, other than comet assays, have also been used (de Azevedo Bentes Monteiro Neto et al., 2011; Malini et al., 2010). DXR was selected through being an effective genotoxic and mutagenic agent in in vivo and in vitro studies (Antunes and Takahashi, 1998; Takeuchi et al., 2008; Dutra et al., 2009; Tan and Porter, 2009; Ribeiro et al., 2010). Apparently, the main mechanisms responsible for DXR genotoxicity are the inhibition of DNA topoisomerase II, the capacitation of DNA intercalating agents, and the generation of free radicals (Ferguson and Denny, 2007; Granados-Principal et al., 2010). Animals of DXR-treated groups received a single intraperitoneal injection of this antitumoral agent, thus evoking marked exposure to the agent tested (Preston et al., 1987). As expected, in the present investigation, DXR induced a significant increase in micronucleus frequency in both bone marrow and peripheral blood erythrocytes, as compared to negative and solvent control groups.

MMS, a potentially carcinogenic alkylating agent, through its capacity to directly break DNA strands, thereby leading to the formation of both DNA monoadducts and crosslinks, causes mutations that involve different base substitutions (Wyatt and Pittman, 2006). MMS causes predominantly methylation in nitrogens of purine rings, which can lead to the formation of apurinic sites (de Azevedo Bentes Monteiro Neto et al., 2011). Our results demonstrated that a single administration of MMS (50 mg/kg i.p.) significantly increased DNA damage in mouse liver cells.

In the present study, all doses of commercial Copaiba oilresin evaluated $(500,1,000$ and $2,000 \mathrm{mg} / \mathrm{kg}$ ) were found not to be genotoxic by the comet assay. In bone marrow and peripheral blood cells, no increase was observed in the frequencies of micronuclei, when receiving acute treatment, as compared to negative controls.

Other essential oils and herbal extracts were not mutagenic in other experimental systems. The toxicity of $L$. cubeba oil, extracted from the fruit, was evaluated with a battery of acute and genetic toxicity tests, thereby indicating that oral $\mathrm{LD}_{50}$ was approximately $4,000 \mathrm{mg} / \mathrm{kg}$ of body 
weight, and genetic toxicity was negative for $\mathrm{MN}$ induction in bone marrow (Luo et al., 2005). Infusions prepared from the bark of Bauhinia variegata also showed no increase in micronuclei frequency, when tested at doses of 300 to $900 \mathrm{mg} / \mathrm{kg}$ b.w. in mice (Agrawal and Pandey, 2009). As revealed by MN tests in bone marrow, treatment of mice with $2,000 \mathrm{mg} / \mathrm{kg}$ b.w. of Copaiba oil from Copaifera martii showed no mutagenic effects (dos Santos et al., 2011).

Chromatographic analysis of methylated Copaiba oil resin and its volatile fraction revealed a high concentration of $\beta$-caryophyllene, described as a main component of several active oils, and with antimicrobial, antiinflammatory and antiallergic activities (Lourens et al., 2004; Sabulal et al., 2006; Passos et al., 2007; Leandro et al., 2012). The diterpene fraction yield $(\mathrm{v} / \mathrm{v})$ was $21 \%$. Copalic acid was the predominant diterpene, followed by other, also relevant, oxidized labdane derivatives, such as hydroxycopalic and acethoxycopalic acid (up to 9\%). The oil-resin used here is rich in labdane diterpenes, as was the case in $C$. multijuga analyzed by Veiga Junior et al. (2007) and Gomes et al. (2007), but different from C. langsdorffi and $C$. reticulata, which were shown to contain some clerodane diterpens.

Copaiba oil genotoxicity has been little studied. $\beta$-caryophyllene, the major constituent of its oil-resin and volatile fractions, besides producing no cytotoxic or genotoxic effects in human lymphocyte cultures, proved to be protective against ethyl methanesulfonate-induced DNA damage (Di Sotto et al., 2010). Nine sesquiterpenic compounds, including caryophyllene-trans, was screened in an Ames test and none of the compounds showed mutagenicity (Gonçalves et al., 2011). Cavalcanti et al. (2006) reported that low concentrations of kaurenoic acid, a bioactive diterpenoid extracted from Copaifera langsdorffii, failed to significantly induce DNA damage or increase micronucleus frequency in V79 cells. Nonetheless, on exposure to higher concentrations ( 30 or $60 \mu \mathrm{g} / \mathrm{mL}$ ), a significant increase in DNA damage became evident.

Concluding, under the experimental conditions employed in this study, the oil-resin itself, and volatile and resinous fractions from commercial Copaiba oil-resin showed no genotoxic or mutagenic effects.

\section{Acknowledgments}

The authors are grateful to Dr. Juliana Carvalho Ribeiro (FCFRP-USP) and MsC Alexandre Ferro Aissa (FMRP-USP) for their excellent technical assistance. This work was sponsored by $\mathrm{CNPq}$ (Conselho Nacional de Desenvolvimento Científico e Tecnológico).

\section{References}

Adams RP (2007) Identification of Essential Oil Components by Gas Chromatography/Mass Spectrometry. 4th edition. Allured Publishing Corporation, Illionois, 698 pp.
Agra MD, Silva KN, Basilio IJLD, de Freitas PF and Barbosa JM (2008) Survey of medicinal plants used in the region Northeast of Brazil. Rev Bras Farmacogn 18:472-508.

Agrawal RC and Pandey S (2009) Evaluation of anticarcinogenic and antimutagenic potential of Bauhinia variegata extract in Swiss albino mice. Asian Pac J Cancer Prev 10:913-916.

Antunes LM and Takahashi CS (1998) Effects of high doses of vitamins $\mathrm{C}$ and $\mathrm{E}$ against doxorubicin-induced chromosomal damage in Wistar rat bone marrow cells. Mutat Res 419:137-143.

Balbani APS, Silva DHS and Montovani JC (2009) Patents of drugs extracted from Brazilian medicinal plants. Expert Opin Ther Pat 19:461-473.

Biavatti MW, Dossin D, Deschamps FC and Lima MdP (2006) Copaiba oil-resin analysis: Contribution to quality control. Rev Bras Farmacogn 16:230-235.

Bonassi S, Znaor A, Ceppi M, Lando C, Chang WP, Holland N, Kirsch-Volders M, Zeiger E, Ban S, Barale R et al. (2007) An increased micronucleus frequency in peripheral blood lymphocytes predicts the risk of cancer in humans. Carcinogenesis 28:625-631.

Cavalcanti BC, Costa-Lotufo LV, Moraes MO, Burbano RR, Silveira ER, Cunha KM, Rao VS, Moura DJ, Rosa RM, Henriques JA et al. (2006) Genotoxicity evaluation of kaurenoic acid, a bioactive diterpenoid present in Copaiba oil. Food Chem Toxicol 44:388-392.

Collins AR (2004) The comet assay for DNA damage and repair: Principles, applications, and limitations. Mol Biotechnol 26:249-261

Comelli Júnior E, Skinovski J, Sigwalt MF, Branco AB, Luz SR and Baulé CdP (2010) Rupture point analysis of intestinal anastomotic healing in rats under the action of pure Copaíba (Copaifera Iangsdorfii) oil. Acta Bras Cir 25:362-367.

de Azevedo Bentes Monteiro Neto M, de Souza Lima IM, Furtado RA, Bastos JK, da Silva Filho AA and Tavares DC (2011) Antigenotoxicity of artepillin $\mathrm{C}$ in vivo evaluated by the micronucleus and comet assays. J Appl Toxicol 31:714-719.

Di Sotto A, Mazzanti G, Carbone F, Hrelia P and Maffei F (2010) Inhibition by beta-caryophyllene of ethyl methanesulfonate-induced clastogenicity in cultured human lymphocytes. Mutat Res 699:23-28.

dos Santos HM, Oliveira DF, de Carvalho DA, Pinto JMA, Campos VAC, Mourao ARB, Pessoa C, de Moraes MO and Costa-Lotufo LV (2010) Evaluation of native and exotic Brazilian plants for anticancer activity. J Nat Med 64:231238.

dos Santos AO, Costa MA, Ueda-Nakamura T, Dias-Filho BP, da Veiga-Junior VF, de Souza Lima MM and Nakamura CV (2011) Leishmania amazonensis: Effects of oral treatment with copaiba oil in mice. Exp Parasitol 129:145-151.

Dutra ES, Dias CD, de Araujo BC, Castro AJ and Nepomuceno JC (2009) Effect of organic tomato (Lycopersicon esculentum) extract on the genotoxicity of doxorubicin in the Drosophila wing spot test. Genet Mol Biol 32:133-137.

Ferguson LR and Denny WA (2007) Genotoxicity of non-covalent interactions: DNA intercalators. Mutat Res 623:14-23.

Gomes NM, Rezende CM, Fontes SP, Matheus ME and Fernandes PD (2007) Antinociceptive activity of Amazonian Copaiba oils. J Ethnopharmacol 109:486-492.

Gonçalves O, Pereira R, Gonçalves F, Mendo S, Coimbra MA and Rocha SM (2011) Evaluation of the mutagenicity of sesqui- 
terpenic compounds and their influence on the susceptibility towards antibiotics of two clinically relevant bacterial strains. Mutat Res 723:18-25.

Granados-Principal S, Quiles JL, Ramirez-Tortosa CL, SanchezRovira P and Ramirez-Tortosa MC (2010) New advances in molecular mechanisms and the prevention of adriamycin toxicity by antioxidant nutrients. Food Chem Toxicol 48:1425-1438.

Hayashi M, Morita T, Kodama Y, Sofuni T and Ishidate M (1990) The micronucleus assay with mouse peripheral-blood reticulocytes using acridine orange-coated slides. Mutat Res 245:245-249.

Knudsen LE and Hansen AM (2007) Biomarkers of intermediate endpoints in environmental and occupational health. Int $\mathbf{J}$ Hyg Environ Health 210:461-470.

Lawrence BM (1988) Progress in essential oil. In: Frey C and Rouseff RL (eds) Natural Flavor and Fragrance Materials. Chemistry, Analysis, and Production. American Chemical Society, Oxford, pp 32.

Leandro LM, de Sousa Vargas F, Barbosa PC, Neves JK, da Silva JA and da Veiga-Junior VF (2012) Chemistry and biological activities of terpenoids from Copaiba (Copaifera spp.) oleoresins. Molecules 17:3866-3889.

Lewis WH (2003) Medical Botany: Plants Affecting Human Health. 2nd edition. John Wiley and Soons, New York, $832 \mathrm{pp}$.

Lourens AC, Reddy D, Baser KH, Viljoen AM and Van Vuuren SF (2004) In vitro biological activity and essential oil composition of four indigenous South African Helichrysum species. J Ethnopharmacol 95:253-258.

Luo M, Jiang LK and Zou GL (2005) Acute and genetic toxicity of essential oil extracted from Litsea cubeba (Lour.) Pers. J Food Prot 68:581-588.

MacGregor JT, Heddle JA, Hite M, Margolin BH, Ramel C, Salamone MF, Tice RR and Wild D (1987) Guidelines for the conduct of micronucleus assays in mammalian bone marrow erythrocytes. Mutat Res 189:103-112.

Malini M, Marin-Morales MA, Mantovani MS, Jamal CM, Nati N, da Silva Passos T and Matsumoto ST (2010) Determination of the antimutagenicity of an aqueous extract of Rhizophora mangle L. (Rhizophoraceae), using in vivo and in vitro test systems. Genet Mol Biol 33:176-181.

Mavournin KH, Blakey DH, Cimino MC, Salamone MF and Heddle JA (1990) The in vivo micronucleus assay in mammalian bone marrow and peripheral blood. A report of the U.S. Environmental Protection Agency Gene-Tox Program. Mutat Res 239:29-80.

Medeiros RD and Vieira G (2008) Sustainability of extraction and production of copaiba (Copaifera multijuga Hayne) oleoresin in Manaus, AM, Brazil. For Ecol Manage 256:282288.

Moller P (2006) The alkaline comet assay: Towards validation in biomonitoring of DNA damaging exposures. Basic Clin Pharmacol Toxicol 98:336-345.

Ohsaki A, Yan LT, Ito S, Edatsugi H, Iwata D and Komoda Y (1994) The isolation and in vivo potent antitumor activity of clerodane diterpenoid from the oleoresin of the Brazilian medicinal plant, Copaifera langsdorfi Desfon. Bioorg Med Chem Lett 4:2889-2892.
Olfert ED, Brenda DVM, Cross BM and McWilliam A (1993) Guide to the Care and use of Experimental Animals. Volume 1. Canadian Council on Animal Care, Ottawa, 298 pp.

Paiva LAF, Gurgel LA, Silva RM, Tome AR, Gramosa NV, Silveira ER, Santos FA and Rao VSN (2002) Antiinflammatory effect of kaurenoic acid, a diterpene from Copaifera langsdorffii on acetic acid-induced colitis in rats. Vascul Pharmacol 39:303-307.

Passos GF, Fernandes ES, da Cunha FM, Ferreira J, Pianowski LF, Campos MM and Calixto JB (2007) Anti-inflammatory and anti-allergic properties of the essential oil and active compounds from Cordia verbenacea. J Ethnopharmacol 110:323-333.

Preston RJ, Dean BJ, Galloway S, Holden H, McFee AF and Shelby M (1987) Mammalian in vivo cytogenetic assays. Analysis of chromosome aberrations in bone marrow cells. Mutat Res 189:157-165.

Ribeiro JC, Antunes LMG, Aissa AF, Darin JDaC, De Rosso VV, Mercadante AZ and Bianchi MdLP (2010) Evaluation of the genotoxic and antigenotoxic effects after acute and subacute treatments with açai pulp (Euterpe oleracea Mart.) on mice using the erythrocytes micronucleus test and the comet assay. Mutat Res 695:22-28.

Rispler DT and Sara J (2011) The impact of complementary and alternative treatment modalities on the care of orthopaedic patients. J Am Acad Orthop Surg 19:634-643.

Rothfuss A. Honma M, Czich A, Aardema MJ, Burlinson B, Galloway S, Hamada S, Kirkland D, Heflich RH, Howe J et al. (2011) Improvement of in vivo genotoxicity assessment: Combination of acute tests and integration into standard toxicity testing. Mutat Res 723:108-120.

Sabulal B, Dan M, Anil JJ, Kurup R, Pradeep NS, Valsamma RK and George V (2006) Caryophyllene-rich rhizome oil of Zingiber nimmonii from South India: Chemical characterization and antimicrobial activity. Phytochemistry 67:2469-2473.

Silva JJD, Guimaraes SB, da Silveira ER, de Vasconcelos PRL, Lima GG, Torres SM and de Vasconcelos RC (2009) Effects of Copaifera langsdorffii Desf. on ischemia-reperfusion of randomized skin flaps in rats. Aesthetic Plast Surg 33:104109.

Singh NP, McCoy MT, Tice RR and Schneider EL (1988) A simple technique for quantitation of low levels of DNA damage in individual cells. Exp Cell Res 175:184-191.

Takeuchi P, Antunes L and Takahashi C (2008) Modulation of doxorubicin-induced clastogenesis in Wistar rat bone marrow cells by vitamin B6. Arch Toxicol 82:869-873.

Tan HH and Porter AG (2009) DNA methyltransferase I is a mediator of doxorubicin-induced genotoxicity in human cancer cells. Biochem Biophys Res Commun 382:462-467.

Tappin MRR, Pereira JFG, Lima LA, Siani AC, Mazzei JL and Ramos MFS (2004) Quantitative chemical analysis for the standardization of copaiba oil by high resolution gas chromatograpy. Quim Nova 27:236-240.

Tice RR, Agurell E, Anderson D, Burlinson B, Hartmann A, Kobayashi H, Miyamae Y, Rojas E, Ryu JC and Sasaki YF (2000) Single cell gel/comet assay: Guidelines for in vitro and in vivo genetic toxicology testing. Environ Mol Mutagen 35:206-221.

Tsuboy MS, Marcarini JC, Luiz RC, Barros IB, Ferreira DT, Ribeiro LR and Mantovani MS (2010) In vitro evaluation of 
the genotoxic activity and apoptosis induction of the extracts of roots and leaves from the medicinal plant Coccoloba mollis (Polygonaceae). J Med Food 13:503-508.

Veiga VF and Pinto AC (2002) The Copaifera L. genus. Quim Nova 25:273-286.

Veiga VF, Zunino L, Calixto JB, Patitucci ML and Pinto AC (2001) Phytochemical and antioedematogenic studies of commercial copaiba oils available in Brazil. Phytother Res 15:476-480.

Veiga Junior VF, Rosas EC, Carvalho MV, Henriques MGMO and Pinto AC (2007) Chemical composition and antiinflammatory activity of copaiba oils from Copaifera cearensis Huber ex Ducke, Copaifera reticulata Ducke and Copaifera multijuga Hayne - A comparative study. J Ethnopharmacol 112:248-254.

Venkatesh P, Shantala B, Jagetia GC, Rao KK and Baliga MS (2007) Modulation of doxorubicin-induced genotoxicity by Aegle marmelos in mouse bone marrow: A micronucleus study. Integr Cancer Ther 6:42-53.

Wyatt MD and Pittman DL (2006) Methylating agents and DNA repair responses: Methylated bases and sources of strand breaks. Chem Res Toxicol 19:1580-1594.

\section{Internet Resources}

Brasil (1996) Agência Nacional de Vigilância Sanitária, Portaria $\mathrm{n}^{\circ} 116 / \mathrm{MS} / \mathrm{SNVS}$ de 8 de agosto de 1996. Norma para estudo da toxicidade e da eficácia de produtos fitoterápicos, http://www.anvisa.gov.br/legis/portarias/116_96.htm (May 2, 2012).

Brasil (2000) Agência Nacional de Vigilância Sanitária, Resolução RDC n ${ }^{\circ} 17$ de 24 de fevereiro de 2000: Dispõe sobre o registro de medicamentos fitoterápicos, http://www.anvisa.gov.br/legis/resol/2000/17_00rdc.htm (May 2, 2012).

Brasil (2011) Tabela 1 - Quantidade e valor dos produtos da extração vegetal e da silvicultura, segundo os principais produtos - $\quad$ Brasil $\quad$ - 2009, http://www.ibge.gov.br/home/estatistica/economia/pevs/20 09/tabelas_pdf/tab01.pdf (May 2, 2012).

Associate Editor: Daisy Maria F. Salvadori

License information: This is an open-access article distributed under the terms of the Creative Commons Attribution License, which permits unrestricted use, distribution, and reproduction in any medium, provided the original work is properly cited. 